\title{
Spatiotemporal Expression Patterns of Metalloproteinases and Their Inhibitors in the Postnatal Developing Rat Cerebellum
}

\author{
Catherine Vaillant, Marianne Didier-Bazès, Agnès Hutter, Marie-Francoise Belin, and Nicole Thomasset \\ Institut National de la Santé et de la Recherche Médicale, U433, Faculté de Médecine Laënnec, \\ 69372 Lyon Cedex 08, France
}

\begin{abstract}
Matrix metalloproteinases (MMPs) are proteolytic enzymes that degrade the components of the extracellular matrix (ECM). The balance between MMPs and their inhibitors [tissue inhibitors of metalloproteinases (TIMPs)] in the pericellular environment determines the most significant proteolytic events in tissue remodeling. In vitro evidence is accumulating that these molecules may be crucial in the maturation of neural cells. Here, we investigated the in vivo expression of MMPs 2, 3, and 9 and TIMPs 1, 2, and 3 in the developing and adult rat cerebellum using immunohistochemistry and in situ hybridization. During postnatal development, all Purkinje (PK) cell somata expressed all the MMPs and TIMPs studied, whereas their growing dendritic trees expressed only MMP 3 and TIMP 3. In the adult, MMP 3 was confined to PK cell bodies, whereas TIMP 3 was expressed in PK cell somata and processes. Irrespective of the developmental stage, Bergmann glial processes contained only MMP 9, but their somata contained both TIMP 1 and MMP 9. In
\end{abstract}

granular cells, MMPs 3 and 9 and TIMPs 1, 2, and 3 were chiefly detected at a time when migration is known to be maximal; except for that of TIMP 1, their expression persisted in the internal granular layer in the adult. The functional relevance of MMP expression was verified by gelatin zymography. MMP 9 activity was maximal on postnatal day 10 (P10) and was detectable at a low level on P15 and in the adult, whereas MMP 2 activity remained similar throughout postnatal development. Regional and cell-specific expression of MMPs and TIMPs closely reflects the successive stages of cerebellar development, thereby suggesting a pivotal role for ECM proteolysis in brain development and plasticity.

Key words: metalloproteinase; tissue inhibitor of metalloproteinase; cerebellum postnatal development; neuronal migration; synaptogenesis; tyramide signal amplification immunohistochemistry; in situ hybridization; gelatin zymography
The matrix metalloproteinases (MMPs) constitute a family of zinc-binding endopeptidases characterized by their ability to degrade the components of the extracellular matrix (ECM), a structural support and physiological regulator of cell growth and differentiation (Bissell et al., 1982; Adams and Watt, 1993). MMPs play a pivotal role in modulating interactions between cells and their microenvironment, mainly through ECM receptors (Damsky and Werb, 1992). MMPs 2, 3, and 9 are involved in physiological tissue remodeling (Matrisian and Hogan, 1990), such as trophoblast implantation (Alexander et al., 1996) and mammary gland development (Talhouk et al., 1992; Thomasset et al., 1998), as well as in pathological events, such as tumor progression and metastatic invasion (Mignatti and Rifkin, 1993). MMP activity is tightly regulated at various levels, including gene transcription, activation of MMP proenzymes, and by endogenous tissue inhibitors of metalloproteinases (TIMPs). The balance between MMPs and TIMPs in the pericellular environment determines the most significant proteolytic events in tissue remodeling. Indeed, excessive cleavage of ECM caused by an im-

\footnotetext{
Received Jan. 14, 1999; revised April 5, 1999; accepted April 6, 1999.

This research was supported by grants from the Institut National de la Santé et de la Recherche Médicale, Rhône-Alpes Region, and the Ligue contre le Cancer. Catherine Vaillant was financially supported by a grant from the Ministère de la Recherche et des Technologies. We thank our colleagues Dr. Hidéo Hakaoka for helpful comments on this manuscript, Dr. Michelle Montange for help with the in situ hybridization, and Dr. Tom Barkas for revision of this manuscript. We thank New England Nuclear (Boston, MA) for their interest in our research and JeanLouis Borach for his photographic work.

Correspondence should be addressed to Dr. Nicole Thomasset, U433, Faculté de Médecine Laënnec, rue Guillaume Paradin, 69372 Lyon Cedex 08, France. Copyright (C) 1999 Society for Neuroscience 0270-6474/99/194994-11\$05.00/0
}

balance of the MMPs/TIMPs ratio confers oncogenicity on 3T3 cells (Khokha et al., 1989), and excessive proteolysis contributes to various brain pathologies (Rosenberg et al., 1992; Nakagawa et al., 1994; Mohanam et al., 1995). Although there is growing evidence for an important role of MMPs in inflammatory disorders of the CNS (Giraudon et al., 1996; Pagenstecher et al., 1998) and in brain tumor progression (Lampert et al., 1998), little is known about the cellular origin and physiological role of MMPs and TIMPs in the CNS. In vitro studies suggest that MMPs are required for neurite outgrowth (Pittman and Williams, 1989; Sheffield et al., 1994), and oligodendrocytes are known to use MMP 9 in migration and process extension (Uhm et al., 1998). MMPs and TIMPs may be expected to be involved in brain development, because extensive cellular migration and remodeling of the ECM are necessary for neural development (Reichardt and Tomaselli, 1991; Condic and Letourneau, 1997; Curran and D’Arcangelo, 1998). Indeed, serine proteinases (urokinase- and tissue-plasminogen activators) and their inhibitors are involved in the postnatal migration of granular cells (Moonen et al., 1982; Seeds et al., 1990), and plasminogen activator, strongly expressed in the adult cerebellum, is likely to play a role in the synaptic remodeling associated with learning and memory (Qian et al., 1993; Seeds et al., 1995; Frey et al., 1996). These previous studies clearly indicate that a precise knowledge of the relative distribution of the major MMPs and TIMPs is indispensable to delineate their possible role in brain development and plasticity.

Here, we used the cerebellum as a model to investigate the spatiotemporal expression patterns of MMPs 2, 3, and 9 and TIMPs 1, 2, and 3 using immunohistochemistry and in situ 
hybridization. MMPs 2 and 9 activity was confirmed by gelatin zymography. Depending on the stage of development, specific and differential expression of MMPs and TIMPs was seen, which may be related to granular cell migration, arborization of Purkinje (PK) cells, and synaptogenesis.

\section{MATERIALS AND METHODS}

\section{Gelatin zymography}

The gelatinase activity of MMP 2 (also known as $72 \mathrm{kDa}$ type IV collagenase or gelatinase A) and MMP 9 (also known as $92 \mathrm{kDa}$ type IV collagenase or gelatinase B) was determined using zymography (protease-substrate gel electrophoresis). This technique involves SDSPAGE of nonreduced protein samples in gels containing the substrate gelatin (Herron et al., 1986)

Five rats at each chosen stage of postnatal development [postnatal day 10 (P10), P15, and adult] were intraperitoneally anesthetized with sodium pentobarbital (12 mg/100 gm of body weight; Sanofi, Libourne, France), and then the cerebellum of each animal was dissected out. One hundred fifty milligrams of tissue was mechanically dispersed, placed in a culture dish without rinsing, and incubated for $12 \mathrm{hr}$ with $500 \mu \mathrm{l}$ of DMEM medium (Life Technologies, Paisley, UK) without serum; this step allowed us to detect the activity of secreted MMPs 2 and 9 in the conditioned medium. Cell loss by lysis was quantified using Trypan blue and was minimal after tissue treatment $(<10 \%)$. Briefly, equal volumes $(20 \mu \mathrm{l})$ of the conditioned medium, normalized for protein concentration, were mixed $1: 4$ with $4 \times$ SDS sample buffer, and $25 \mu \mathrm{l}$ of the mixture was loaded into a well of a $10 \%$ zymography gel copolymerized with $0.1 \%$ gelatin. After electrophoresis, the gels were washed with $2.5 \%$ Triton X-100 for $30 \mathrm{~min}$ at room temperature and then incubated overnight at $37^{\circ} \mathrm{C}$ in $100 \mathrm{~mm}$ Tris buffer, $\mathrm{pH} 7.4$, containing $15 \mathrm{~mm} \mathrm{CaCl}_{2}$. They were then fixed with $30 \%$ methanol-10\% acetic acid, stained with $0.25 \%$ Coomassie blue R-250 (Sigma, St. Louis, MO), and destained with $10 \%$ methanol-10\% acetic acid. Enzyme activity, attributable to MMPs 2 and 9 on the basis of their respective molecular weights, was visualized in the gelatin-containing zymograms as clear bands on a blue background. For inhibition of metalloproteinase activity, the gels were incubated with $4 \mathrm{~mm}$ 1,10-pheanthroline as described previously (Adler et al., 1990).

\section{Immunohistochemistry}

Animals and tissue preparation. Experiments were performed on five Sprague Dawley rats (Iffa Credo, L'Arbresle, France) at each stage of postnatal development studied (P10, P15, and the 200-250 gm adult). Animals were intraperitoneally anesthetized with sodium pentobarbital (12 mg/100 gm of body weight; Sanofi, Libourne, France) and intracardially perfused with $50 \mathrm{ml}$ of $0.1 \mathrm{M}$ phosphate buffer, $\mathrm{pH} 7.4$, followed by $300 \mathrm{ml}$ of fixative consisting of $4 \%$ paraformaldehyde and $5 \%$ sucrose in $0.1 \mathrm{~m}$ phosphate buffer, $\mathrm{pH}$ 7.4. The brains were removed, post-fixed for $24 \mathrm{hr}$ at $4^{\circ} \mathrm{C}$ in the same fixative, and immersed for $5 \mathrm{~d}$ in $0.1 \mathrm{M}$ phosphate buffer, $\mathrm{pH} 7.4$, containing $20 \%$ sucrose, before being frozen in isopentane at $-50^{\circ} \mathrm{C}$ using liquid nitrogen and embedded in O.C.T. compound (Tissue Tek, Elkhart, IN). Cryostat sections $(10-\mu \mathrm{m}$-thick) were cut and fixed to glass slides precoated with $2 \%$ aminopropyltriethoxysilane (Fluka, Buchs, Switzerland). All animals were treated according to the guidelines approved by the French Ethical Committee (decree 87-848).

Immunohistochemical analysis. Immunohistochemistry was performed on the slides using a tyramide signal amplification (TSA) kit (New England Nuclear, Boston, MA), which enhances fluorescent signals by a factor of up to 1000-fold (Van Heusden et al., 1997). The TSA technique uses fluorescein-labeled tyramide as the substrate for horse radish peroxidase, which catalyzes the formation of highly reactive tyramide radicals with a very short half-life, thus allowing the binding of fluoresceinconjugated tyramide to tyrosine residues only at the site of enzymatic reaction. This amplification was essential to detect the expression of MMPs 2, 3, and 9 and TIMPs 1, 2, and 3 in the cerebellar cortex of the postnatal and adult rats. The amplified immunohistochemical signals were highly specific, because no labeling was seen using nonimmune sera (data not shown).

The primary polyclonal rabbit antibodies, used at a 1:2500 dilution, were anti-MMP 2 (hinge region), anti-MMP 3 (hinge region), anti-MMP 9 (N-terminal region of the active form), anti-TIMP 1 (C-terminal region), anti-TIMP 2, and anti-TIMP 3 (Chemicon, Temecula, CA). The primary antibodies were raised against human MMPs and TIMPs but recognize the rat proteins; their specificity was verified by Western blots using an extract of adult rat cerebellum (data not shown).

The secondary antibody, used at a 1:1000 dilution, was biotinylated goat anti-rabbit IgG (Jackson ImmunoResearch, West Grove, PA).

Slices were permeabilized for $1 \mathrm{hr}$ at room temperature in $0.1 \mathrm{~m}$ PBS, pH 7.4, containing $0.25 \%$ Triton X-100 and $1 \%$ bovine serum albumin (Sigma), and then fixed in methanol at $-20^{\circ} \mathrm{C}$ for $15 \mathrm{~min}$. Endogenous peroxidase activity was blocked by treating the slides for $15 \mathrm{~min}$ at room temperature with $3 \%$ hydrogen peroxide in methanol, and then the slides were washed at room temperature (three times) in TNT buffer $(0.1 \mathrm{M}$ Tris-HCl, pH 7.5, containing $0.15 \mathrm{M} \mathrm{NaCl}$ and $0.05 \%$ Tween 20). Nonspecific binding sites were saturated by incubation for $15 \mathrm{~min}$ at $37^{\circ} \mathrm{C}$ with TNT buffer plus $5 \%$ normal goat serum, followed by incubation for 30 min with TNB blocking buffer $(0.1 \mathrm{~m}$ Tris- $\mathrm{HCl}, \mathrm{pH} 7.5,0.15 \mathrm{M} \mathrm{NaCl}$, and $0.1 \%$ of the blocking reagent supplied in the kit). The sections were incubated initially overnight at $4^{\circ} \mathrm{C}$ with primary antibody diluted in TNB and then, after washing, for $2 \mathrm{hr}$ at room temperature with biotinylated secondary antibody diluted in TNT buffer before being incubated with streptavidin-conjugated horse radish peroxidase for $30 \mathrm{~min}$ at room temperature, followed by washing with TNT. The fluorophore tyramide, diluted 1:50 with the diluent supplied in the kit, was added to the slides for $10 \mathrm{~min}$ at room temperature. After washing, the slides were mounted in PBS containing 50\% glycerol for FITC-fluorescence microscopy (Axioskop FS; Zeiss, Jena, Germany). Controls consisted of the omission of the primary antibody or incubation with a nonreactive normal rabbit serum (Vector Laboratories, Burlingame, CA).

Bergmann glial cells were characterized using mouse monoclonal anti-vimentin antibody at a 1:200 dilution (Sigma) in PBS, and PK cells were stained using mouse monoclonal anti-calbindin-D antibody at a 1:200 dilution (Dako, Carpinteria, CA) in PBS. The secondary FITCconjugated anti-mouse antibodies were used at a 1:1000 dilution in PBS.

\section{In situ hybridization}

Preparation of tissue. Three rats at each of the two chosen stages (P10 and adult) were intraperitoneally anesthetized with sodium pentobarbital (Sanofi), intracardially perfused with $50 \mathrm{ml}$ of $0.1 \mathrm{M}$ phosphate buffer, $\mathrm{pH}$ 7.4 , followed by $300 \mathrm{ml}$ of fixative containing $2 \%$ paraformaldehyde, and then decapitated. The brains were removed and post-fixed for $1 \mathrm{hr}$ at $4{ }^{\circ} \mathrm{C}$ in the same fixative before being immersed in $20 \%$ sucrose in $0.1 \mathrm{M}$ phosphate buffer, $\mathrm{pH} 7.4$, for $2 \mathrm{~d}$. The samples were frozen in isopentane at $-50^{\circ} \mathrm{C}$ using liquid nitrogen and embedded in O.C.T. compound (Tissue Tek). Cryostat sections (12- $\mu$ m-thick) were cut and fixed to glass slides precoated with $2 \%$ aminopropyltriethoxysilane (Fluka) and then dehydrated in a graded series of ethanol.

Hybridization probes. Three antisense oligodeoxynucleotide probes, specific for MMP 9, TIMP 2, or TIMP 3, were provided by Biognostik (Göttingen, Germany). The rat MMP 9, TIMP 2, and TIMP 3 hybriprobes were, respectively, 29, 29, and 30 bases long and targeted the region between bases 689 and 717, 309 and 337, and 422 and 451 of the respective total sequence. The probes were $3^{\prime}$ labeled for $1 \mathrm{hr}$ at $37^{\circ} \mathrm{C}$ using $5 \mathrm{pm}$ probe in a final volume of $10 \mu \mathrm{l}$ of $2.5 \mathrm{mM} \mathrm{CoCl}_{2}, 17 \mathrm{pM} \alpha^{35} \mathrm{~S}$ dATP $(1250 \mathrm{Ci} / \mathrm{mmol}$; New England Nuclear) and $22 \mathrm{U}$ of terminal deoxynucleotidyl transferase (Boehringer Mannheim, Mannheim, Germany). The probes were separated from nonincorporated nucleotides by Micro Spin column chromatography through Bio-Gel polyacrylamide (Bio-Rad, Hercules, CA) and then diluted with $500 \mu$ l of hybridization buffer (Hybribuffer; Biognostik). Eighty microlitres of the mixture was added to each of the sections, which were then incubated overnight at $39^{\circ} \mathrm{C}$ in a sealed humid container, and the slides were sequentially washed at room temperature for $1 \mathrm{hr}$ once with $2 \times \mathrm{SSC}(1 \times \mathrm{SSC}$ : $0.15 \mathrm{~m}$ sodium chloride, $0.015 \mathrm{~m}$ sodium citrate, $\mathrm{pH} 7.0$ ), once with $1 \times \mathrm{SSC}$, and twice with $0.5 \times$ SSC. After dehydration in a graded alcohol series, the slides were air-dried and exposed for $5 \mathrm{~d}$ to a Hyperfilm- $\beta$ max film (Amersham, Arlington Heights, IL); they were then dipped in Kodak NTB-2 emulsion (Eastman Kodak, Rochester, NY), dried, and stored in the dark for 4 weeks before being developed, counterstained with toluidine blue, and examined by dark- and bright-field microscopy.

When hybridization specificity was verified by hybridizing some sections in the presence of an excess (100-fold) of unlabeled probe, a substantially reduced signal was obtained (data not shown).

Cresyl violet was used to examine the general histology in cryostat sections adjacent to those used for immunohistochemistry. The neuronal classes were defined using the criteria of their position and the size of the nuclei, as described by Altman (1972a,b,c). PK cells were also character- 
ized using anti-calbindin-D antibody (Enderlin et al., 1987). On P10, small round cells in the external granular layer (EGL) were identified as granular cells, whereas spindle-shaped cells descending along Bergmann glia fibers in the molecular layer (ML) were identified as migrating granular cells (Altman, 1972a; Komuro and Rakic, 1998). Medium and large cells in the ML were classified as ML cells and identified as either basket or stellate neurons on the basis of their morphology. Other cells were classified as ML neurons when located above the PK cell layer (PCL). Small cells encircling the PK cell bodies were classified as Bergmann glial cells. Small cells in the internal granular layer (IGL) were identified as granular neurons.

\section{RESULTS}

Three stages of postnatal development of the cerebellum, P10, $\mathrm{P} 15$, and the adult, were chosen for immunohistochemical study because of the major events occurring at these times during maturation. The P10 stage corresponds to the beginning of a sharp decline in the thickness of the EGL, caused by extensive and rapid granular cell precursor migration through the ML and PCL (Altman, 1972a). On P15, cerebellar development is marked by intensive outgrowth of PK cell dendritic branches in the ML. Growth occurs mainly in the secondary and tertiary branches and terminal branchlets bearing spines (Altman, 1972b). Synaptogenesis between parallel fibers and the dendritic PK tree ascends progressively from the PK cell somata toward the EGL. In the adult, granule cells from the EGL have migrated to give rise to the IGL. Various cellular and molecular mechanisms underlie this coordinated proliferation, migration, and synaptogenesis. Of the molecules involved, the functional domains of ECM components have been shown to be important in regulating cell attachment, migration, and process extension during development (Reichardt and Tomaselli, 1991). These functional domains of the ECM are generated by proteolysis involving several proteolytic enzymes because of their diverse macromolecular composition. Thus, multiple metalloproteinase family members could be involved. We therefore examined gelatinase activity in the developing and adult cerebellum.

\section{Gelatinase activity in the developing and adult rat cerebellum}

MMPs are expressed and secreted as inactive precursors that are activated by the removal of an N-terminal propeptide (Okada et al., 1988). Important physiological activators of pro-MMPs are plasmin, a serine proteinase generated from plasminogen by the action of tissue or urokinase-plasminogen activator, or other proteinases (Basbaum and Werb, 1996). The latent and active forms of each enzyme can be differentiated on the basis of their molecular weights (MW). In the rat cerebellum, MMP 9 activity was high on P10 but barely detectable on P15 and in the adult (Fig. 1); MMP 9 was found to be in the active form $(87 \mathrm{kDa})$, with the latent form $(92 \mathrm{kDa})$ being undetectable. MMP 2 activity was constant throughout postnatal development and was higher than MMP 9 activity on P15 and in the adult. Furthermore, MMP 2 existed as both the latent and active forms (MW of the latent form, $72 \mathrm{kDa}$; MW of the active forms, 66 and $64 \mathrm{kDa}$ ) at all three stages. To determine their cellular origin and specific localization in the developing cerebellum, we determined their regional and cellular patterns of expression using immunohistochemistry and in situ hybridization.

\section{Immunohistochemical distribution patterns of MMPs 2, 3 , and 9 and TIMPs 1, 2, and 3 in the P10 rat cerebellum}

In the EGL, subsets of cell bodies, described as granular cell precursors, were strongly labeled by antibodies specific for MMP

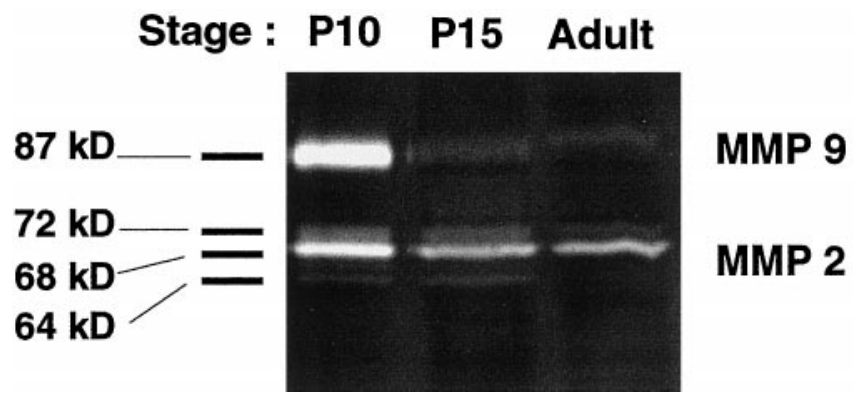

Figure 1. SDS-PAGE zymographic analysis of MMP activity in the rat cerebellum. Rat cerebellum extracts from P10, P15, or adult were examined. For each stage, $150 \mathrm{mg}$ of tissue cerebellum was plated in tissue dish with $500 \mu \mathrm{l}$ of DMEM without serum. After $12 \mathrm{hr}, 20 \mu \mathrm{l}$ of this conditioned medium at the same protein concentration was analyzed for MMP 2 and MMP 9 activity using SDS-PAGE zymography with gelatin as substrate. The active form of MMP $9(87 \mathrm{kDa})$ and the latent form $(72$ $\mathrm{kDa})$, as well as active forms (66 kDa, $64 \mathrm{kDa})$, of MMP 2 can be seen. The image was obtained by scanning the gel and using Adobe (San Jose, CA) Photoshop software to generate a digital image.

3 (Fig. 2B), MMP 9 (Fig. 2C), TIMP 1 (Fig. 2D), or TIMP 2 (Fig. $2 E$ ) and weakly labeled by anti-TIMP 3 antibodies (Fig. $2 F$ ); MMP 2 expression was undetectable (Fig. $2 A$ ). In addition, MMP 9 (Fig. 2C) was expressed in thin parallel processes reaching the pial surface, which were identified as Bergmann glial fibers (Altman, 1972a) by double labeling with anti-vimentin antibodies (data not shown). In the ML, PK cell dendrites, characterized by their positive calbindin-D immunoreactivity (data not shown), were intensely stained with antibodies specific for MMP 9 (Fig. $2 C$ ) or TIMP 3 (Fig. $2 F$ ) and weakly stained with antibodies specific for MMP 2 (Fig. $2 A$ ), MMP 3 (Fig. $2 B$ ), or TIMP 1 (Fig. $2 D$ ). MMP 3 (Fig. $2 B$ ), MMP 9 (Fig. 2C), TIMP 1 (Fig. 2D), and TIMP 2 (Fig. $2 E$ ) were present in both the cell body and the extracellular space, whereas TIMP 3 (Fig. $2 F$ ) was strictly restricted to the PK cell arborization. In the PCL, PK cell somata stained positive for all the markers but to a varying extent. MMP 9 (Fig. 2C) and TIMP 1 (Fig. 2D) were also found in small cell bodies corresponding to Bergmann glial somata surrounding labeled and unlabeled PK cell somata. In the IGL, expression of MMPs 3 (Fig. 2B) and 9 (Fig. 2C) and all TIMPs tested was detectable in some granular cells, sparsely distributed throughout the layer. The heterogeneous labeling observed may represent modulation of MMP expression by the local environment, which can cause arrest of granular cells migration (Komuro and Rakic, 1998).

\section{Immunohistochemical distribution patterns of MMPs 2, 3 , and 9 and TIMPs 1, 2, and 3 in the P15 rat cerebellum}

On P15, when the thickness of the EGL is restricted to three or four layers of cells, MMP 2 (Fig. 3A), MMP 9 (Fig. 3C), TIMP 1 (Fig. 3D), TIMP 2 (Fig. $3 E$ ), and TIMP 3 (Fig. $3 F$ ) were undetectable in granular cell precursors; a few residual precursors exhibited MMP 3 reactivity (Fig. 3B). In the ML, numerous fibers, arising from PK cell somata on some section planes and corresponding to the enlarged PK cell dendrites arborization, and other fibers, possibly corresponding to portions of Bergmann glia fibers, were labeled by anti-MMP 3 antibodies (Fig. $3 B$ ). This staining was intense but diffuse, suggesting secretion into the extracellular environment, whereas TIMP 3 expression (Fig. $3 F$ ) 


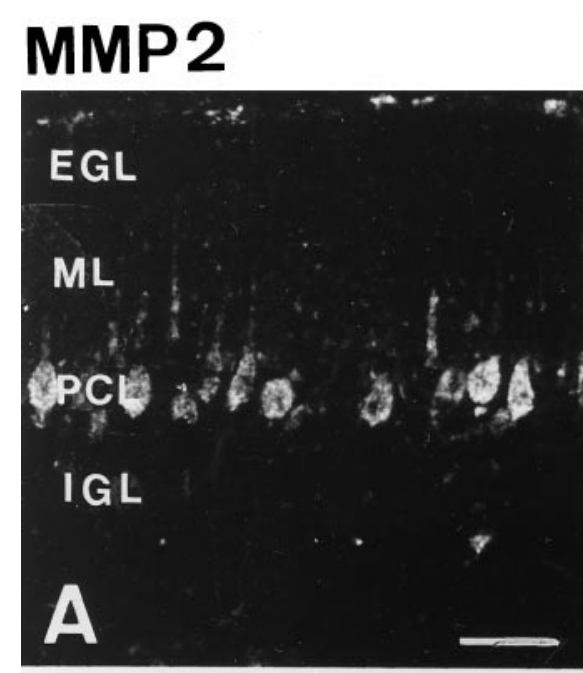

MMP3
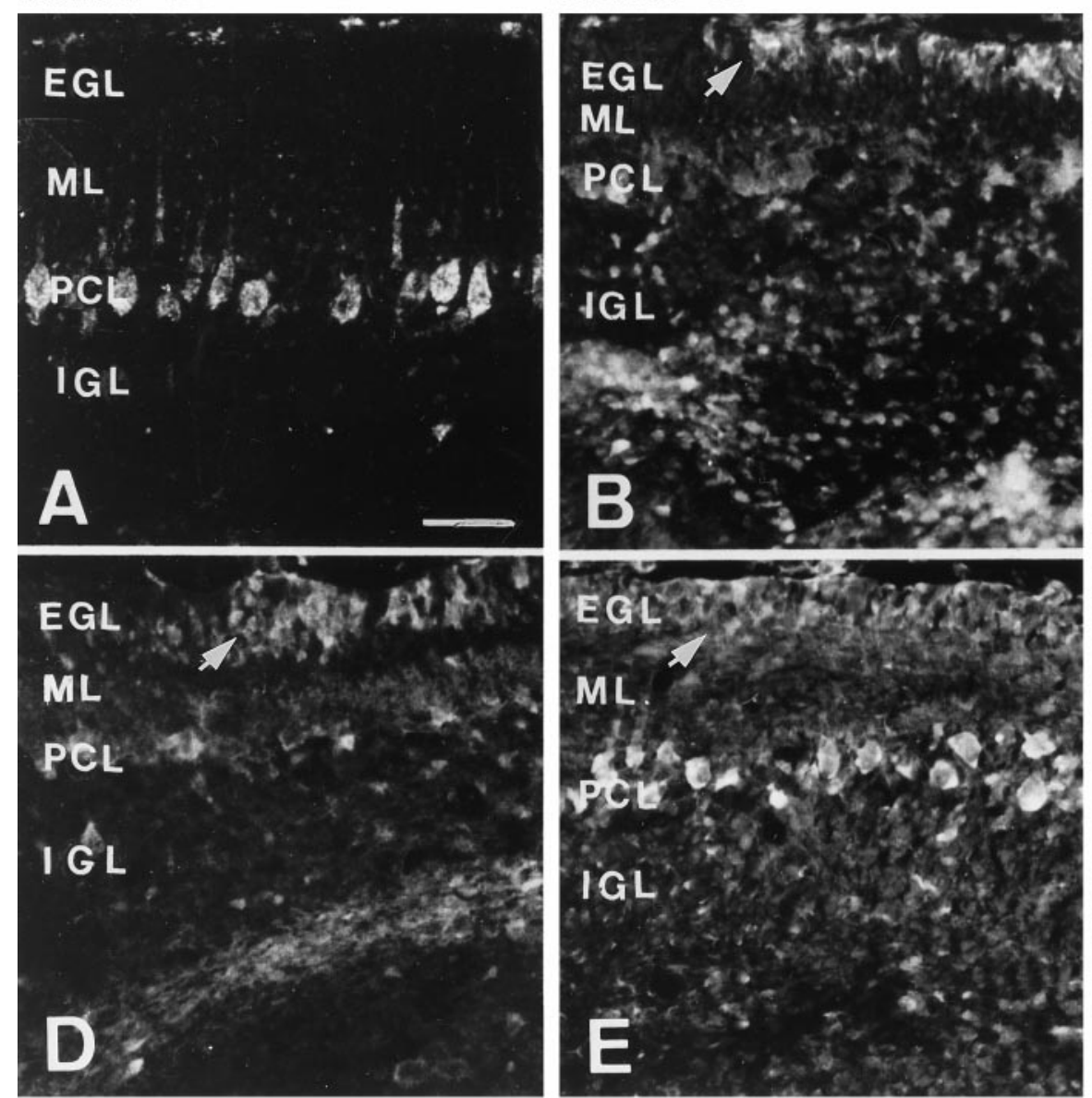
TIMP1

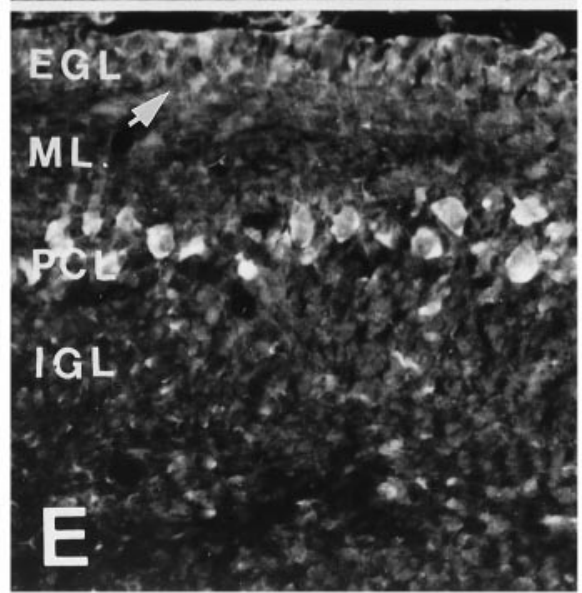

TIMP2
MMP9
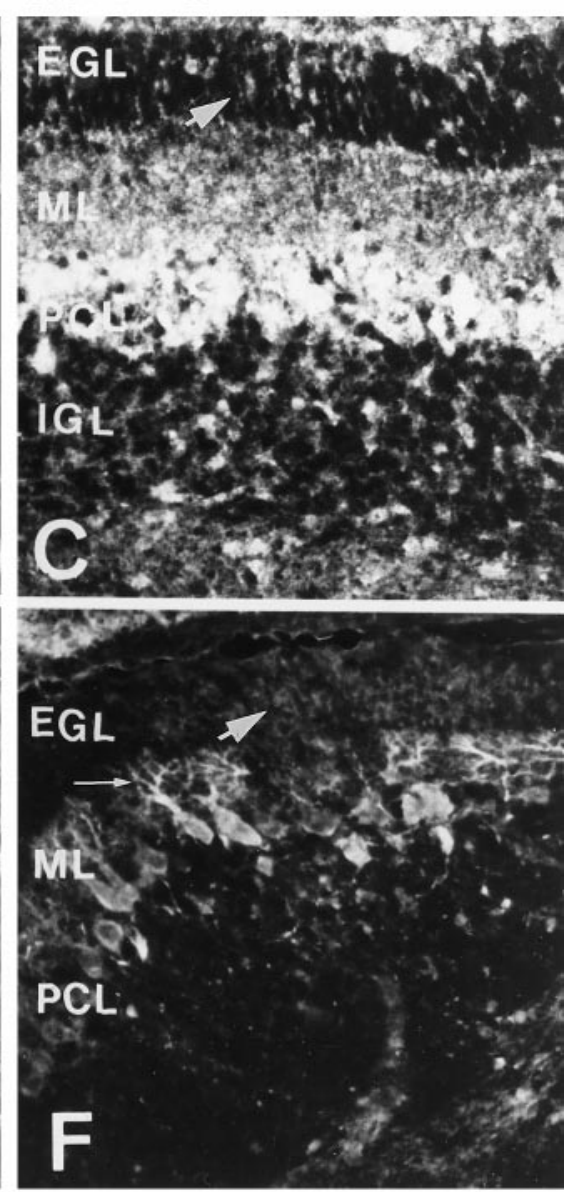

TIMP3

Figure 2. Immunohistochemical distribution pattern of MMP $2(A)$, MMP $3(B)$, MMP $9(C)$, TIMP $1(D)$, TIMP $2(E)$, and TIMP $3(F)$ in the cerebellar cortex of 10-d-old rats. Immunohistochemical labeling was performed on 10- $\mu \mathrm{m}$-thick frontal rat cerebellar sections showing the EGL, the ML, the PCL, and the IGL. The labeling with polyclonal antibodies was enhanced using the fluorescein tyramide signal amplification system (New England Nuclear). In the EGL, MMP $3(B)$, MMP $9(C)$, TIMP $1(D)$, TIMP $2(E)$, and to less extents for TIMP $3(F)$, were seen in granular precursor cells. In addition, MMP 9 was detected along the Bergmann glial fibers in this layer $(C)$. Arrows point to strips of stained granular precursor cells. In the ML, MMP 3, MMP 9, and TIMP 1 were diff usely present over PK cells dendrites, whereas TIMP 3 was restricted to the cytoplasm of the PK cell dendrites (the small arrow in $F$ points to the labeled PK cell dendritic arborization). In the PCL, the PK cell somata showed labeling for each marker, and MMP 9 expression was seen in the Bergmann glial cell somata. Some granular cells in the IGL were immunopositive for MMPs 3 and 9 and TIMPs 1, 2, and 3. Scale bar, $50 \mu \mathrm{m}$.

was confined to PK dendritic branches. MMP 9 (Fig. 3C) and TIMP 1 (Fig. 3D) dendritic staining was very weak compared with that seen on P10. MMP 9 (Fig. 3C) was also detected in small cells, probably corresponding to basket and stellate interneurons, and also along Bergmann glial cell processes. In the PCL, Bergmann glial somata were positive for MMP 9 (Fig. 3C) and TIMP 1 (Fig. 3D). MMP 2 (Fig. $3 A$ ), MMP 3 (Fig. $3 B$ ), MMP 9 (Fig. $3 C$ ), and TIMP 3 (Fig. $3 F$ ) could all be detected in all PK cell somata to varying extents. Only TIMP 2 (Fig. 3E) was homogeneously and strongly expressed in all PK somata. The TIMP 1 expression pattern (Fig. 3D) in PK somata made it possible to distinguish two types of PK populations, consisting either of patches of TIMP 1-positive PK cell somata, restricted to parts of the cerebellar hemispheres, or clusters of unlabeled PK cell somata. A few granular cells in the IGL were positive for all markers except MMP 2 and TIMP 2.
Immunohistochemical distribution patterns of MMPs 2, 3 , and 9 and TIMPs 1, 2, and 3 in the adult rat cerebellum

In contrast with the expression patterns seen on P10 and P15, that of a more diffuse distribution in the extracellular space around the cells, expression of MMPs and TIMPs in the adult was mainly confined to cell bodies.

In the ML, the PK cell dendritic trees showed no labeling for MMP 2 (Fig. 4A), MMP 3 (Fig. 4B), MMP 9 (Fig. 4C), TIMP 1 (Fig. $4 D$ ), or TIMP 2 (Fig. $4 E$ ). Only TIMP 3 (Fig. $4 F$ ) was detected in the dendritic elongations of all PK cells. The immunostained processes showed varicosities, which may correspond to PK cell synaptic glomeruli (Altman, 1972b). MMP 3 (Fig. 4B), MMP 9 (Fig. 4C), TIMP 1 (Fig. 4D), and TIMP 2 (Fig. 4E) were strongly expressed in numerous cell bodies described as interneurons. MMP 9 expression (Fig. 4C) was maintained along the 
MMP2
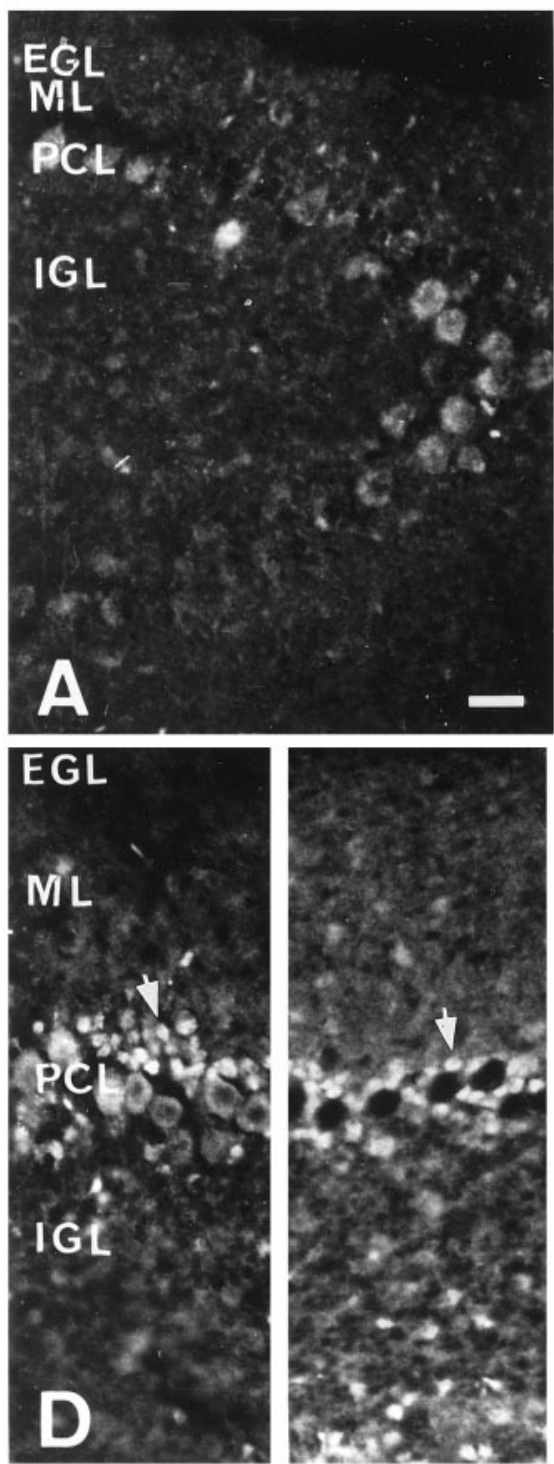

TIMP1

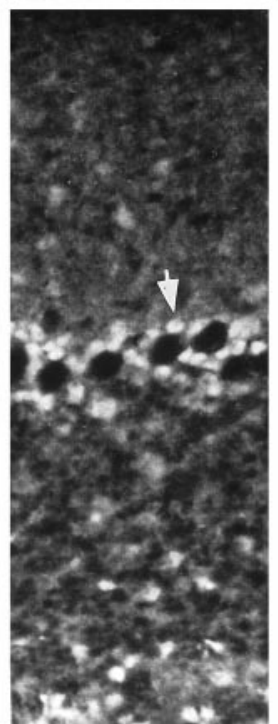

MMP3
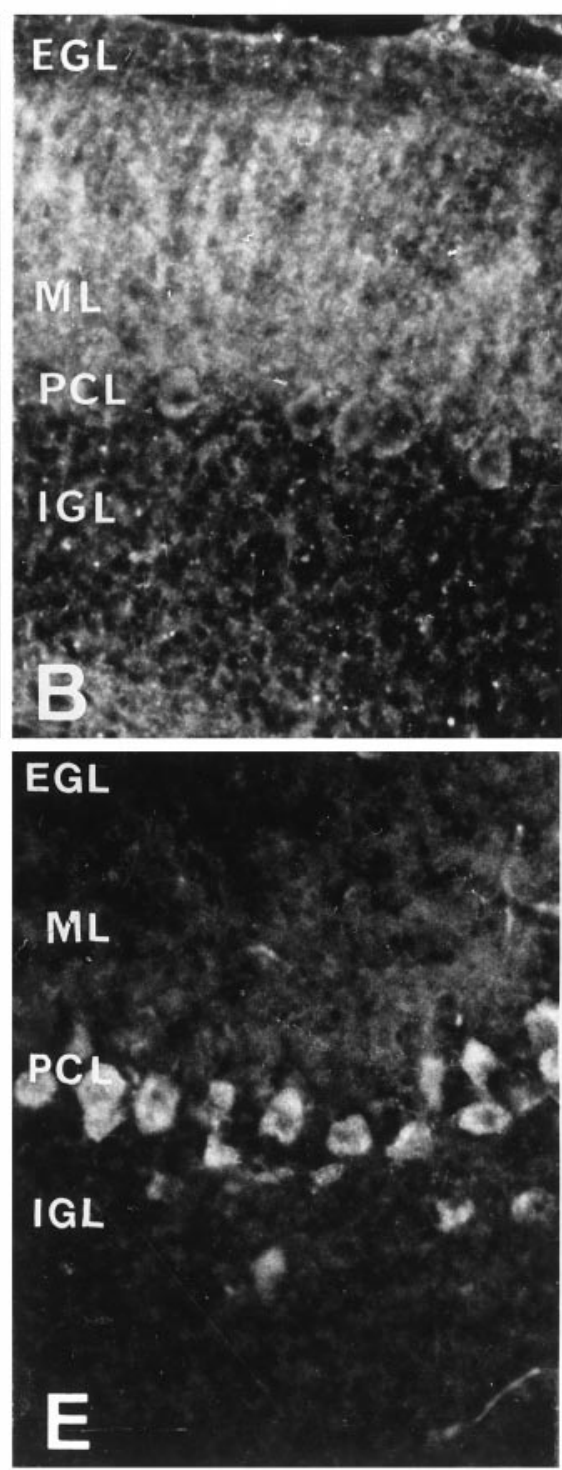

TIMP2
MMP 9
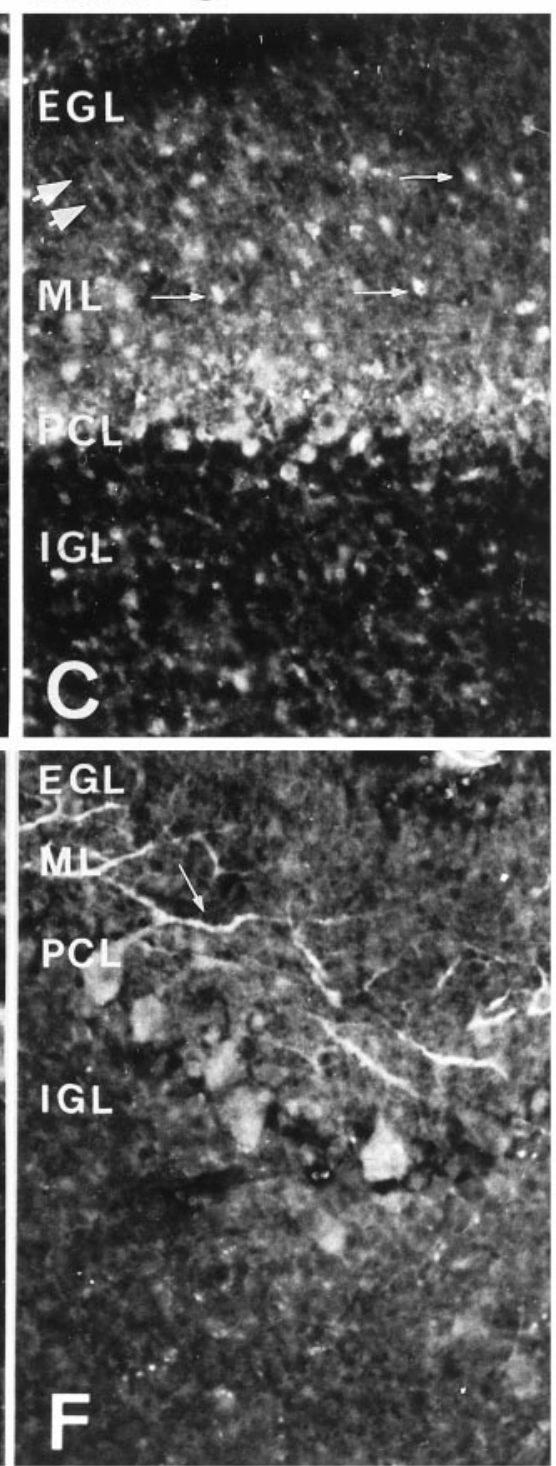

TIMP 3

Figure 3. Immunohistochemical distribution pattern of MMP $2(A)$, MMP $3(B)$, MMP $9(C)$, TIMP $1(D)$, TIMP $2(E)$, and TIMP $3(F)$ in the cerebellar cortex of 15-d-old rats. Ten-micrometer-thick frontal sections of rat cerebellum showed the EGL, the ML, the PCL, and the IGL. Immunohistochemical staining was performed using polyclonal antibodies and amplified by tyramide signal amplification (New England Nuclear). EGL immunostaining for MMPs 3 and 9 and TIMPs 1, 2, and 3 was lost. The PK cell dendrites were still stained for MMP 3 and TIMP 3. Note the diff use extracellular distribution of MMP 3 as opposed to the cytoplasmic distribution of TIMP 3 . ML labeling for MMP 9 and TIMP 1 in the PK cell dendrites decreased, but MMP 9 labeling of Bergmann glial fibers was maintained. MMP 9 labeling in ML cells, probably corresponding to stellate and basket cells, was detected. The large double arrows point to MMP 9-positive Bergmann glial fibers, and the small arrows point to MMP 9-positive ML cells ( $C$ ). In the PCL, expression of MMPs 2, 3, and 9 and TIMPs 1, 2, and 3 was noted in the PK cell somata. TIMP 1 was differentially expressed in clusters of PK cell somata (stained and unstained PK cell somata are respectively indicated by large arrows at the left and right of $D$ ). TIMP 1 was also present in Bergmann glial somata around labeled and unlabeled PK cell bodies $(D)$. Granular cells in the IGL were positive for MMPs 3 and 9 and TIMPs 1 and 3. Scale bar, $25 \mu \mathrm{m}$.

Bergmann glial processes. In the PCL, MMP 2 (Fig. $4 A$ ), MMP 3 (Fig. 4B), MMP 9 (Fig. 4C), TIMP 1 (Fig. 4D), TIMP 2 (Fig. $4 E$ ), and TIMP 3 (Fig. $4 F$ ) were expressed in PK cell somata, and MMP 9 (Fig. 4C) and TIMP 1 (Fig. 4D) were still detectable in the Bergmann glial somata. In the IGL, MMP 3 (Fig. 4B), MMP 9 (Fig. 4C), TIMP 2 (Fig. 4D), and TIMP 3 (Fig. 4F) were strongly expressed in many granular cells, whereas TIMP 1 (Fig. $4 D$ ) was poorly expressed, except along large unidentified fibers in the IGL and in the white matter, probably corresponding to PK cell axons.

Spatiotemporal distribution of MMP 9, TIMP 2, and TIMP 3 mRNA expression in the P10 and adult rat cerebellum

MMP and TIMP transcriptional expression was investigated to determine whether protein expression corresponded to cellular 


\section{MMP 2}
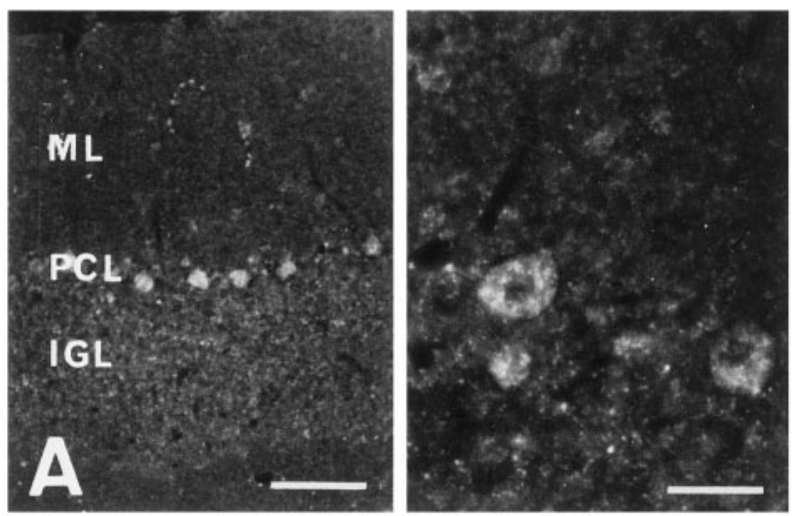

\section{MMP 3}
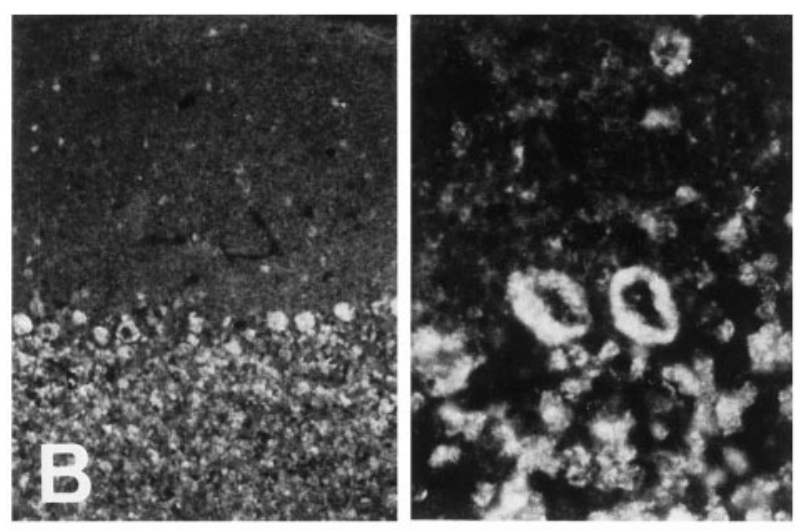

\section{MMP 9}
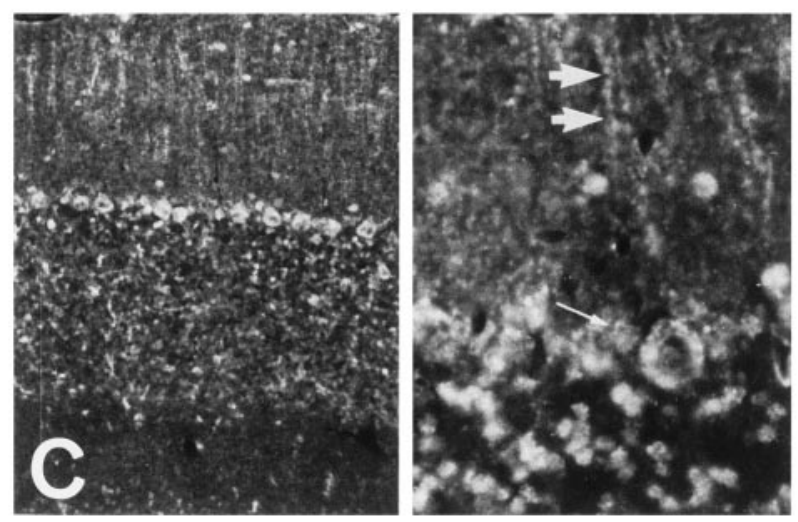

\section{TIMP1}
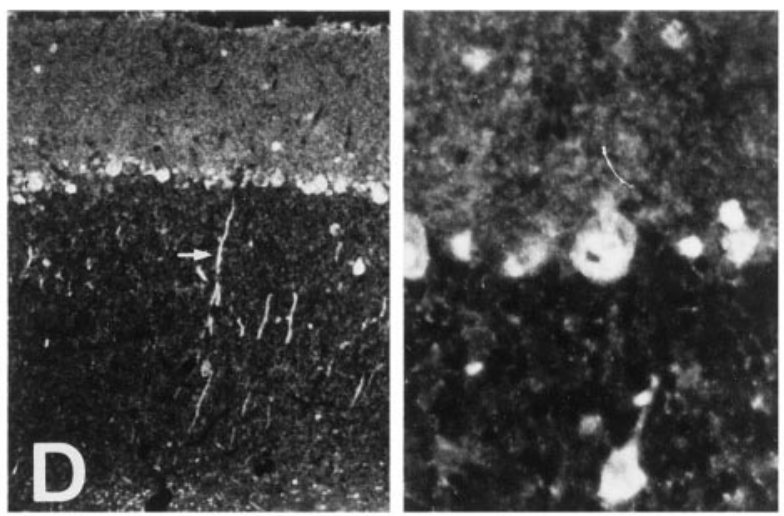

\section{TIMP 2}
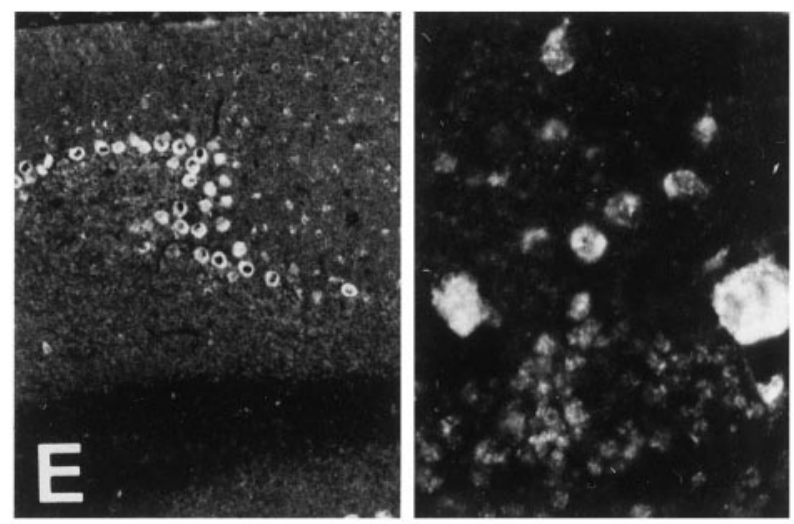

TIMP 3
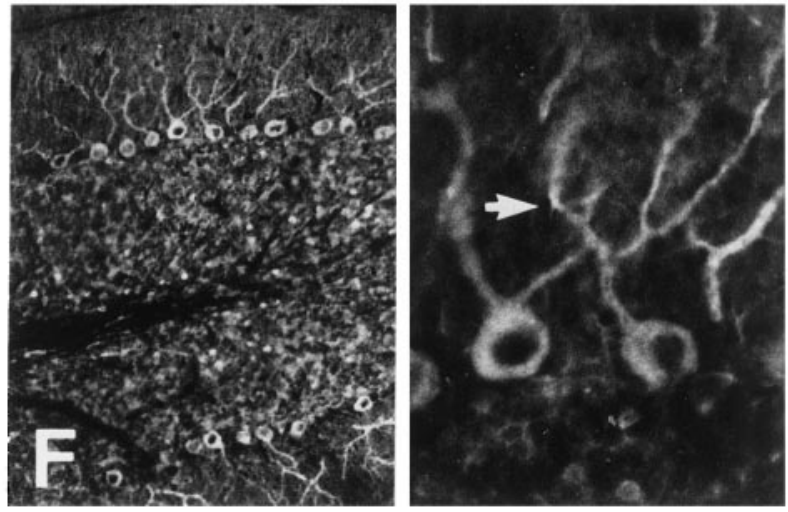

Figure 4. Immunohistochemical distribution pattern of MMP $2(A)$, MMP $3(B)$, MMP $9(C)$, TIMP 1 (D), TIMP $2(E)$, and TIMP $3(F)$ in adult rat cerebellar cortex. Ten micrometer frontal sections of adult rat cerebellum showed the EGL, the ML, the PCL, and the IGL. Labeling with polyclonal antibodies was amplified by using tyramide signal amplification (New England Nuclear). Note, for each marker, the cytoplasmic staining at the adult age compared with the diff use staining seen on the developmental stages P10 and P15. In the ML, MMPs 3 and 9 and TIMPs 1, 2, and 3 protein expression was lost in PK cell arborization. However, MMP 9 expression persisted in the Bergmann glial fibers. Double arrows point to one fiber in $C$. Only the anti-TIMP 3 antibodies labeled PK cells dendrites. Arrow indicates TIMP 3 dendritic immunolabeling in $F$. Interneurons of the ML were labeled for MMPs 3 and 9 and TIMPs 1 and 2. In the PCL, all markers were detected in PK cell somata. In addition, MMP 9 and TIMP 1 were seen in the Bergmann glial cell bodies surrounding the PK cell somata. In the IGL, MMPs 3 and 9 and TIMPs 2 and 3 were strongly expressed in many granular cells, whereas TIMP 1 was poorly expressed. Magnification of the left of each panel, $100 \times$. Magnification of the right of each panel, $400 \times$. Scale bars, $100 \mu \mathrm{m}$. 
synthesis. Expression of MMP 9, TIMP 2, and TIMP 3 mRNAs was studied by in situ hybridization in the P10 and adult rat cerebellum (Fig. 5). Regional mRNA distribution in the cerebellar layers was analyzed using autoradiographic film, and the cellular transcriptional distribution was determined using the same sections coated with emulsion. The regional and cellular differences between MMP 9, TIMP 2, and TIMP 3 mRNA patterns were in general agreement with the immunohistochemical patterns. However, TIMP 3 mRNA was absent from the dendrites of PK cells, and thus, did not colocalize with its encoded protein in this area.

On P10, the EGL was significantly labeled for MMP 9 mRNA over the whole cerebellar cortex on autoradiographic film. MMP 9 mRNA was faintly detectable in the ML, whereas the PCL and IGL were strongly stained (Fig. $5 A$ ). In the adult, labeling was detected in the PCL and IGL (Fig. 5B). MMP 9 transcripts were confined to ML interneurons and PK somata (Fig. $5 C$ ).

On P10, TIMP 2 mRNA was detected in the whole EGL and in the PCL on autoradiographic film (Fig. 5D). In the adult, strong labeling was seen in the PCL and IGL (Fig. 5E). At high magnification, ML interneurons and the whole PK cell layer were shown to be labeled. Some clusters of granular cells were also stained in the IGL (Fig. $5 F$ ).

On P10, strong expression of TIMP 3 transcripts was noticed in the EGL, whereas the ML was unstained and appeared as a black line (Fig. 5G). The PCL and IGL were strongly labeled. In the adult, labeling was localized to the PCL and IGL (Fig. 5H). At high magnification, staining of ML interneurons and PK cell somata was seen (Fig. 5I).

\section{DISCUSSION}

Cerebellar ontogenesis is characterized by postnatal directional migration, differentiation, and synaptogenesis with precise spatiotemporal order of positioning, leading to three highly organized cellular layers. In the adult, the cerebellar cortex requires synaptic remodeling of PK cell inputs for motor tasks and the learning of complex motor skills. MMPs, by focalized and controlled proteolysis, may be crucial in determining the hierarchy of processes involved in brain development and plasticity. This hypothesis was supported by the differential and spatiotemporal expression of MMPs 2, 3, and 9 and TIMPs 1, 2, and 3 during cerebellar development. These regional and cellular expression patterns are evidence for tightly regulated proteolysis-mediated alteration of ECM components, which might be related to the migration of granular precursors and PK cell arborization.

\section{Differential expressions of MMPs 2, 3, and 9 in granular precursors and PK cells in the rat developing cerebellum}

Between birth and P14, the EGL of the cerebellum contains rapidly dividing precursor cells that migrate inward and cross the expanding ML to reach their final position in the IGL (Rakic, 1971; Komuro and Rakic, 1998), the peak of this migratory activity occurring between P7 and P10 (Altman, 1972a). The expression of MMPs 3 and 9 on P10 in EGL cells may be related to the migration of granular cell precursors. In fact, it has been demonstrated that these molecules are required for cell migration in the morphogenesis of the mandibular arch (Chin and Werb, 1997). MMPs act by degrading or activating cell surface proteins and ECM proteins, revealing cryptic domains that signal in a different manner to the intact protein. Interestingly, MMP 3 is known to cleave tenascin into different domains (Imai et al.,
1994). These different domains in the fibronectin type III repeats of tenascin promote the migration of granular cells in the EGL (Chuong et al., 1987; Bartsch et al., 1992) and neurite outgrowth (Husmann et al., 1992). In addition, MMP 3 and MMP 9 are able to cleave laminin, another ECM molecule, which contains a domain on its B2 chain that inhibits the migration of granular cells (Liesi et al., 1992) and which has been localized to the PK/Bergmann cell area of the developing cerebellum (Liesi et al., 1995). Thus, MMPs 3 and 9 could be involved in the migration of cerebellar cell precursors by causing local proteolysis and thus modifying cell signaling by the presence or absence of ECM molecules in different parts of the cerebellum. This hypothesis is corroborated by the dramatic decrease in MMP 9 activity on P15, when the rate of granular precursors migration declines (Altman, 1972a).

In the developing ML, granular cell migration is guided by surface-mediated interactions with Bergmann glial processes (Rakic, 1971, 1990; Edmondson and Hatten, 1987); MMP 9, specifically expressed in Bergmann glial fibers, could contribute to this migration.

In contrast, despite its high activity revealed by zymography, MMP 2 was confined to PK cell bodies and was undetectable in the EGL and ML at all stages of development. MMP 2 has the unique ability of being activated at the cell surface in response to particular matrix proteins (Deryugina et al., 1997, 1998; Strongin et al., 1995). Its ability to cleave the fibroblast growth factor receptor (FGFR) (Levi et al., 1996) could be of interest in the context of the cerebellum, because FGFR and FGF expression is tightly regulated in the developing postnatal cerebellum in relation to proliferation and migration (Hatten et al., 1988; Tao et al., 1996; Hattori et al., 1997).

The expression of MMPs 3 and 9 in PK cell bodies and their proximal dendrites on $\mathrm{P} 10$ and $\mathrm{P} 15$ coincides with the arborization of PK cells (confirmed by calbindin-D immunolabeling of the PK dendritic tree; our unpublished observations), when parallel fibers start to form synapses with the outgrowing dendritic spines and the lower stellate cells begin to establish connections (Altman, 1972b). The strong diff use expression of MMPs 3 and 9 in this area, compared with that in the adult cerebellum, may reflect the release of the enzyme into the pericellular environment of the PK cells. A role for metalloproteinases in axonal growth and pathfinding has recently received support from findings showing that axons stall and fail to extend through the nerve cord in the metalloproteinase gene-defective Drosophila mutant, Kuzbanian (Fambrough et al., 1996). In addition, MMP 3 has been shown to mediate PC 12 cell growth cone penetration through basal laminae (Nordstrom et al., 1995), whereas metalloproteinase inhibitors inhibit growth cone retinal activity (Sheffield et al., 1994). Thus, axonal growth might require spatial and temporal regulation of ECM degradation at the cell surface, and the growing dendrites and growth cones may use focalized proteolysis in a similar way to that proposed for other migrating cells (Basbaum and Werb, 1996).

\section{Expression of TIMPs 1, 2, and 3 in relation to MMPs in the rat developing cerebellum}

TIMPs 1, 2, and 3 are equally potent against all active forms of these enzymes (Goldberg et al., 1989; Kleiner and StetlerStevenson, 1993). Nevertheless, TIMP 1 or TIMP 2 preferentially complex with the proenzyme form of MMP 9 or MMP 2, respectively (Goldberg et al., 1992; Strongin et al., 1993). The colocalization of MMPs 3 and 9 with TIMPs 1, 2, and 3 in PK cell 


\section{P10}

\section{MP 9}

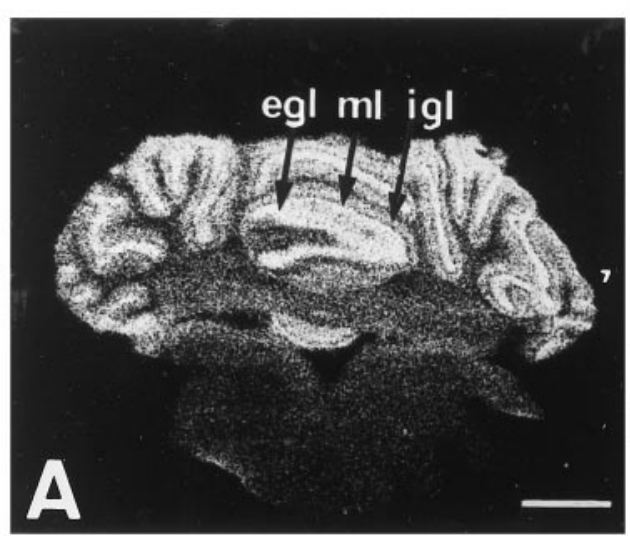

\section{TIMP 2}

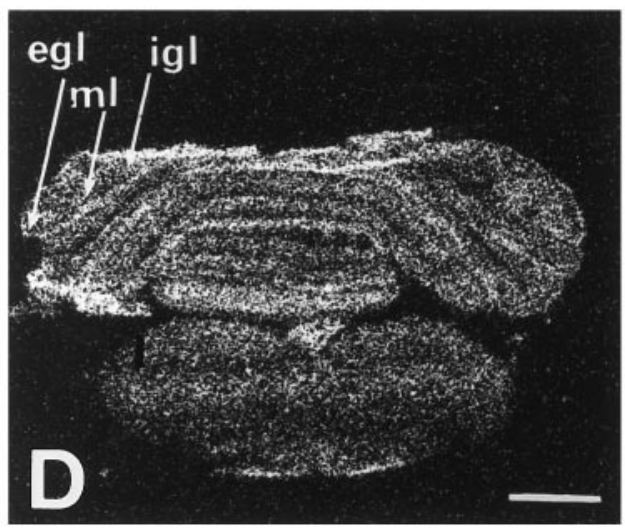

\section{TIMP 3}

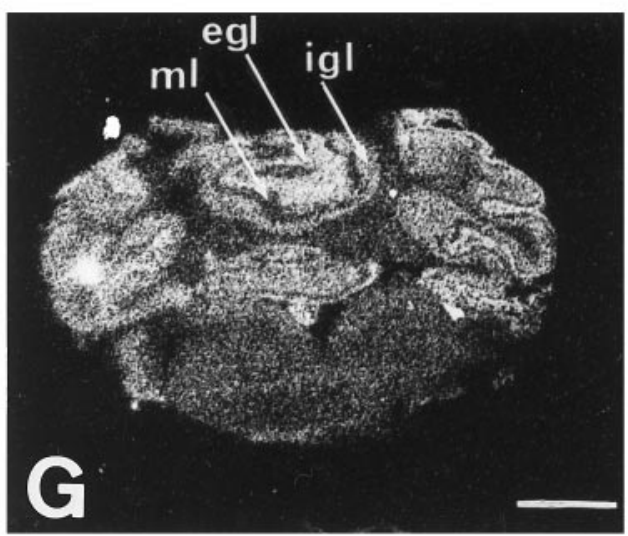

\section{ADULT}
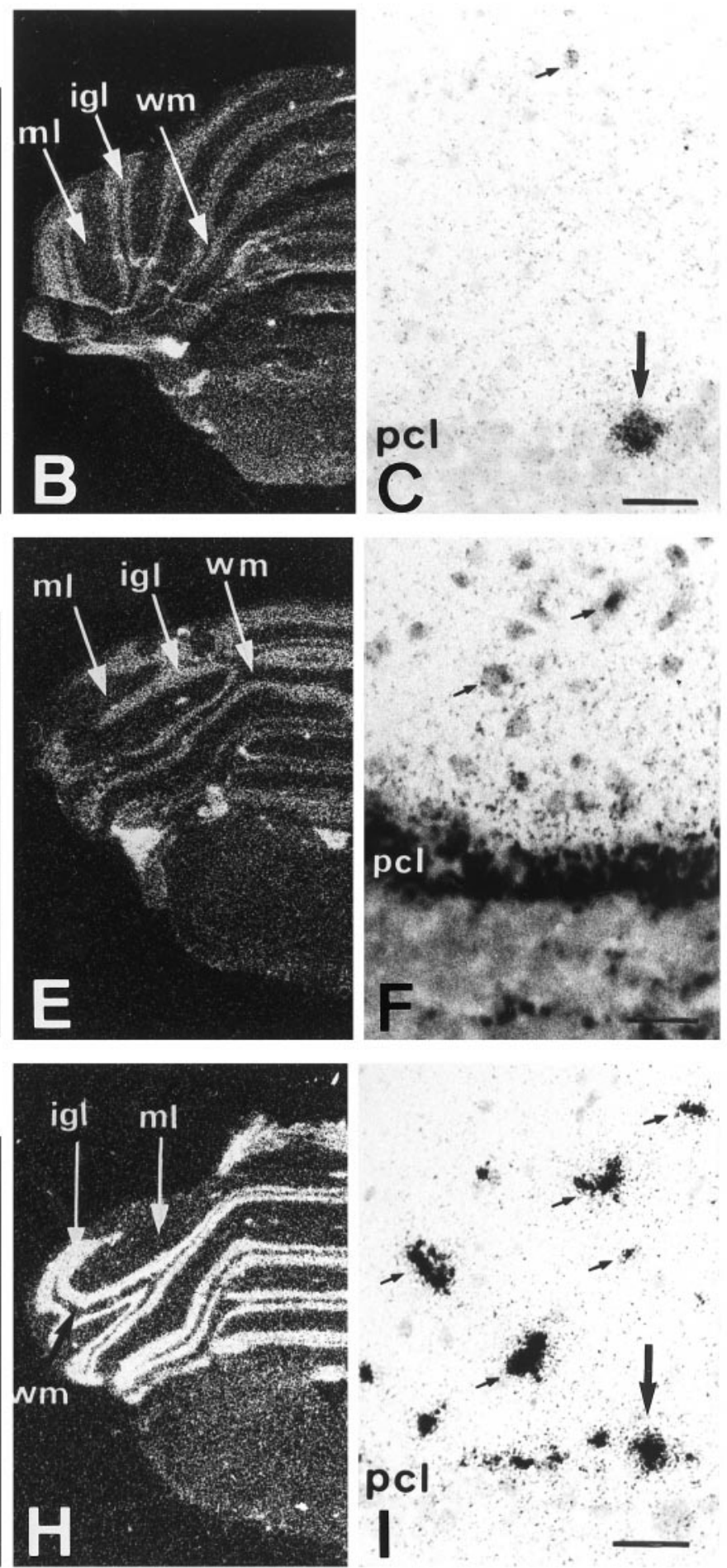

Figure 5. Differential distribution of MMP $9(A-C)$, TIMP $2(D-F)$, and TIMP $3(G-I)$ transcripts in the developing and adult rat cerebellum. In situ hybridization was performed on frontal rat cerebellum sections $(12 \mu \mathrm{m})$ using antisense MMP 9, TIMP 2, and TIMP 3 mRNA oligoprobes provided by Biognostik. Autoradiographic film images $(A, B, D, E, G, H)$ were obtained by exposure for $5 \mathrm{~d}$ on Hyperfilm- $\beta$ max film (Amersham). The exposure time for the emulsion-coated sections $(C, F, I)$ was 6 weeks. On P10, MMP 9 mRNA was intensely expressed in the whole EGL and weakly expressed in the ML, PCL, and IGL $(A)$. In the adult, the global labeling was restricted to the PCL and IGL $(B)$. MMP 9 mRNA subcellular expression was detected in ML interneurons (small arrows) and PK cell somata (large arrows) (C). TIMP 2 mRNA expression was mainly observed in the EGL on P10 $(D)$ and in the PCL and IGL in the adult $(E)$. On emulsion-coated sections, TIMP 2 was visible in the ML interneurons (small arrows), in the border of PK cell somata, and in the IGL $(F)$. On P10, TIMP3 transcript expression was high in the EGL $(G)$. No expression of TIMP 3 was seen in the ML on autoradiographic films, but labeling for TIMP 3 was seen in the PCL and IGL of the $10 \mathrm{~d}$ cerebellum $(G)$. In the adult, labeling was faint in the ML and high in the PCL and IGL $(H)$. TIMP 3 mRNA was seen in the ML interneurons (small arrows) and in some PK cell somata (large arrow) ( $I$ ). WM, White matter. Scale bars: $A, D, G, 1$ and $3 \mathrm{~mm} ; C, F, I, 40 \mu \mathrm{m}$. 
bodies at each stage of cerebellar development and in the EGL on P10 suggests an exquisite balance between the enzymes and their inhibitors, which controls the activation and stability of gelatinases, allowing controlled focalized proteolysis, crucial for granular migration and synaptogenesis.

Interestingly, TIMP 1 (and only TIMP 1) is expressed on P15 in clusters of PK cell bodies, distributed in alternating longitudinal stripes. A similar heterogeneity has been seen during postnatal development in the expression of certain proteins, such as homologs of segment-polarity proteins (Oberdick et al., 1993), and adhesion-guidance molecules (Chedotal et al., 1996; Arndt and Redies, 1998). The latter are considered to be recognition signals involved in the formation of the climbing fiber projections emerging from the inferior olive and pointing to the PK cells (Wassef et al., 1992). As TIMP 1 expression coincides with maturation of the climbing fiber afferent system (Mason and Gregory, 1984; Sotelo et al., 1984), this molecule could be involved in olivocerebellar connections.

Independent of its inhibitory effect on MMPs, there is evidence that TIMP 2 may act as a cytokine and stimulate cell proliferation (Hayakawa et al., 1994; Corcoran et al., 1995). This could be relevant to the TIMP 2 expression seen in the EGL (an idea further supported by the absence of MMP 2) at a time when the proliferation and migration of granular cells peak (Rex et al., 1998). In addition, TIMP 3 expression presents a unique pattern localized along the dendrites of PK cells. Unlike TIMPs 1 and 2, which are secreted in a soluble form (Polette et al., 1994), TIMP 3 is associated with the ECM (Leco et al., 1994) and inhibits MMPs 1, 2, 3, and 9 (Apte et al., 1995; Will et al., 1996). In addition, TIMP 3 inhibits the adhesion of melanoma cells to collagens and fibronectin (Ahonen et al., 1998). Thus, in addition to balancing MMP activity during PK cell maturation, TIMP 3 could reduce the attachment of PK cell dendrites to the ECM, facilitating arborization of PK cells and synaptogenesis. As TIMP 3 is restricted to a few tissues that exhibit high metabolic activity or rapid turnover (Zeng et al., 1998), its specific distribution in PK dendrites in the adult cerebellum suggests that TIMP 3 expression could facilitate cerebellar plasticity.

\section{Expression of MMPs 2, 3, and 9 and TIMPs 1, 2, and 3 in the adult cerebellum}

The adult cerebellum is an area of plasticity that supports the learning of specific motor tasks (Gilbert, 1974). This plasticity is associated with an increase in the number of synapses per PK cell (Black et al., 1990). Several proteases, such as calpain and plasminogen activator, which are implicated in synaptic plasticity (Denny et al., 1990; Huang et al., 1996) and induced in PK cells (Seeds et al., 1995, 1996), act by degrading cell surface receptors and cell adhesion molecules to eliminate synapses or ECM molecules, thus exposing cryptic adhesion sites for new synapse formation. Thus, MMPs 3 and 9, which are activated by the plasminogen-plasmin system, and TIMPs 2 and 3, present in the adult cerebellum in which extracellular matrix remodeling is still important, may play a role in synaptic integrity and plasticity.

In conclusion, the differential expression patterns of the various MMPs and TIMPs provides a new insight into the focalized and controlled proteolysis occurring during cerebellar development. The spatiotemporal regulation of MMPs-TIMPs may be crucial in granular cell migration and the maturation of PK cells and, more generally, in brain maturation and plasticity.

\section{REFERENCES}

Adams JC, Watt FM (1993) Regulation of development and differentiation by the extracellular matrix. Development 117:1183-1198.

Adler RR, Brenner CA, Werb Z (1990) Expression of extracellular matrix-degrading metalloproteinases and metalloproteinase inhibitors is developmentally regulated during endoderm differentiation of embryonal carcinoma cells. Development 110:211-220.

Ahonen M, Baker AH, Kahari VM (1998) Adenovirus-mediated gene delivery of tissue inhibitor of metalloproteinases-3 inhibits invasion and induces apoptosis in melanoma cells. Cancer Res 58:2310-2315.

Alexander CM, Hansell EJ, Behrendtsen O, Flannery ML, Kishnani NS, Hawkes SP, Werb Z (1996) Expression and function of matrix metalloproteinases and their inhibitors at the maternal-embryonic boundary during mouse embryo implantation. Development 122:1723-1736.

Altman J (1972a) Postnatal development of the cerebellar cortex in the rat. The external germinal layer and the transitional molecular layer. J Comp Neurol 145:353-397.

Altman J (1972b) Postnatal development of the cerebellar cortex in the rat. II. Phases in the maturation of Purkinje cells and of the molecular layer. J Comp Neurol 145:399-463.

Altman J (1972c) Postnatal development of the cerebellar cortex in the rat. III. Maturation of the components of the granular layer. J Comp Neurol 145:465-513.

Apte SS, Olsen BR, Murphy G (1995) The gene structure of tissue inhibitor of metalloproteinases (TIMP-3) and its inhibitory activities define the distinct TIMP gene family. J Biol Chem 270:14313-14318.

Arndt K, Redies C (1998) Development of cadherin-defined parasagittal subdivisions in the embryonic chicken cerebellum. J Comp Neurol 401:367-381.

Bartsch S, Bartsch U, Dörries U, Faissner A, Weller A, Ekblom P, Schachner M (1992) Expression of tenascin in the developing and adult cerebellar cortex. J Neurosci 12:736-749.

Basbaum CB, Werb Z (1996) Focalized proteolysis: spatial and temporal regulation of extracellular matrix degradation at the cell surface. Curr Opin Cell Biol 8:731-738.

Bissell MJ, Hall HG, Parry G (1982) How does the extracellular matrix direct gene expression? J Theor Biol 99:31-68.

Black JE, Isaacs KR, Anderson BJ, Alcantara AA, Greenough WT (1990) Learning causes synaptogenesis, whereas motor activity causes angiogenesis, in cerebellar cortex of adult rats. Proc Natl Acad Sci USA 87:5568-5572.

Chedotal A, Pourquie O, Ezan F, San Clemente H, Sotelo C (1996) BEN as a presumptive target recognition molecule during the development of the olivocerebellar system. J Neurosci 16:3296-3310.

Chin JR, Werb Z (1997) Matrix metalloproteinases regulate morphogenesis, migration and remodeling of epithelium, tongue skeletal muscle and cartilage in the mandibular arch. Development 124:1519-1530.

Chuong CM, Crossin KL, Edelman GM (1987) Sequential expression and differential function of multiple adhesion molecules during the formation of cerebellar cortical layers. J Cell Biol 104:331-342.

Condic ML, Letourneau PC (1997) Ligand-induced changes in integrin expression regulate neuronal adhesion and neurite outgrowth. Nature 389:852-856.

Corcoran M, Kleiner DJ, Stetler-Stevenson W (1995) Regulation of matrix metalloproteinases during extracellular matrix turnover. Adv Exp Med Biol 385:151-159.

Curran T, D'Arcangelo G (1998) Role of reelin in the control of brain development. Brain Res Rev 26:285-294.

Damsky CH, Werb Z (1992) Signal transduction by integrin receptors for extracellular matrix: cooperative processing of extracellular information. Curr Opin Cell Biol 4:772-781.

Denny JB, Polan-Curtain J, Ghuman A, Wayner MJ, Armstrong DL (1990) Calpain inhibitors block long-term potentiation. Brain Res 534:317-320.

Deryugina EI, Bourdon MA, Luo GX, Reisfeld RA, Strongin A (1997) Matrix metalloproteinase-2 activation modulates glioma cell migration. J Cell Sci 110:2473-2482.

Deryugina EI, Bourdon MA, Reisfeld RA, Strongin A (1998) Remodeling of collagen matrix by human tumor cells requires activation and cell surface association of matrix metalloproteinase-2. Cancer Res 58:3743-3750.

Edmondson JC, Hatten ME (1987) Glial-guided granular neuron migration in vitro: a high-resolution time-lapse video microscopic study. J Neurosci 7:1928-1934.

Enderlin S, Norman AW, Celio MR (1987) Ontogeny of the calcium 
binding protein calbindin D-28k in the rat nervous system. Anat Embryol 177:15-28.

Fambrough D, Pan D, Rubin GM, Goodman CS (1996) The cell surface metalloprotease/disintegrin Kuzbanian is required for axonal extension in Drosophila. Proc Natl Acad Sci USA 93:13233-13238.

Frey U, Muller M, Kuhl D (1996) A different form of long-lasting potentiation revealed in tissue plasminogen activator mutant mice. J Neurosci 16:2057-2063.

Gilbert PF (1974) A theory of memory that explains the function and structure of the cerebellum. Brain Res 70:1-18.

Giraudon P, Buart S, Bernard A, Thomasset N, Belin MF (1996) Extracellular matrix-remodeling metalloproteinases and infection of the central nervous system with retrovirus human T-lymphotropic virus type I (HTLVI). Prog Neurobiol 49:169-184.

Goldberg GI, Marmer BL, Grant GA, Eisen AZ, Wilhelm S, He CS (1989) Human 72-kilodalton type IV collagenase forms a complex with a tissue inhibitor of metalloproteases designated TIMP-2. Proc Natl Acad Sci USA 86:8207-8211.

Goldberg GI, Strongin A, Collier IE, Genrich LT, Marmer BL (1992) Interaction of $92-\mathrm{kDa}$ type IV collagenase with the tissue inhibitor of metalloproteinases prevents dimerization, complex formation with interstitial collagenase, and activation of the proenzyme with stromelysin. J Biol Chem 267:4583-4591.

Hatten ME, Lynch M, Rydel RE, Sanchez J, Joseph-Silverstein J, Moscatelli D, Rifkin DB (1988) In vitro neurite extension by granule neurons is dependent upon astroglial-derived fibroblast growth factor. Dev Biol 125:280-289.

Hattori Y, Miyake A, Mikami T, Ohta M, Itoh N (1997) Transient expression of FGF-5 mRNA in the rat cerebellar cortex during postnatal development. Brain Res Mol Brain Res 47:262-266.

Hayakawa T, Yamashita K, Shinagawa E (1994) Cell growth-promoting activity of tissue inhibitor of metalloproteinases-2 (TIMP-2). J Cell Sci 107:2373-2379.

Herron GS, Werb Z, Dwyer K, Banda MJ (1986) Secretion of metalloproteinases by stimulated capillary endothelial cells. I. Production of procollagenase and prostromelysin exceeds expression of proteolytic activity. J Biol Chem 261:2810-2813.

Huang YY, Bach ME, Lipp HP, Zhuo M, Wolfer DP, Hawkins RD, Schoonjans L, Kandel ER, Godfraind JM, Mulligan R, Collen D, Carmeliet P (1996) Mice lacking the gene encoding tissue-type plasminogen activator show a selective interference with late-phase longterm potentiation in both Schaffer collateral and mossy fiber pathways. Proc Natl Acad Sci USA 93:8699-8704.

Husmann K, Faissner A, Schachner M (1992) Tenascin promotes cerebellar granular cell migration and neurite outgrowth by different domains in the fibronectin type III repeats. J Cell Biol 116:1475-1486.

Imai K, Kusakabe M, Sakakura T, Nakanishi I, Okada Y (1994) Susceptibility of tenascin to degradation by matrix metalloproteinases and serine proteinases. FEBS Lett 352:216-218.

Khokha R, Waterhouse P, Yagel S, Lala PK, Overall CM, Norton G, Denhardt DT (1989) Antisense RNA-induced reduction in murine TIMP levels confers oncogenicity on Swiss 3T3 cells. Science 243:947-950.

Kleiner Jr DE, Stetler-Stevenson WG (1993) Structural biochemistry and activation of matrix metalloproteases. Curr Opin Cell Biol 5:891-897.

Komuro H, Rakic P (1998) Distinct modes of neuronal migration in different domains of developing cerebellar cortex. J Neurosci 18:1478-1490.

Lampert K, Machein U, Machein MR, Conca W, Peter HH, Volk B (1998) Expression of matrix metalloproteinases and their tissue inhibitors in human brain tumors. Am J Pathol 153:429-437.

Leco KJ, Khokha R, Pavloff N, Hawkes SP, Edwards DR (1994) Tissue inhibitor of metalloproteinases-3 (TIMP-3) is an extracellular matrixassociated protein with a distinctive pattern of expression in mouse cells and tissues. J Biol Chem 269:9352-9360.

Levi E, Fridman R, Miao HQ, Ma YS, Yayon A, Vlodavsky I (1996) Matrix metalloproteinase 2 releases active soluble ectodomain of fibroblast growth factor receptor 1. Proc Natl Acad Sci USA 93:7069-7074.

Liesi P, Seppala I, Trenkner E (1992) Neuronal migration in cerebellar microcultures is inhibited by antibodies against a neurite outgrowth domain of laminin. J Neurosci Res 33:170-176.

Liesi P, Hager G, Dodt HU, Seppala I, Zieglgansberger W (1995)
Domain-specific antibodies against the B2 chain of laminin inhibit neuronal migration in the neonatal rat cerebellum. J Neurosci Res 40:199-206.

Mason CA, Gregory E (1984) Postnatal maturation of cerebellar mossy and climbing fibers: transient expression of dual features on single axons. J Neurosci 4:1715-1735.

Matrisian LM, Hogan BL (1990) Growth factor-regulated proteases and extracellular matrix remodeling during mammalian development. Curr Top Dev Biol 24:219-259.

Mignatti P, Rifkin DB (1993) Biology and biochemistry of proteinases in tumor invasion. Physiol Rev 73:161-195.

Mohanam S, Wang SW, Rayford A, Yamamoto M, Sawaya R, Nakajima M, Liotta LA, Nicolson GL, Stetler-Stevenson WG, Rao JS (1995) Expression of tissue inhibitors of metalloproteinases: negative regulators of human glioblastoma invasion in vivo. Clin Exp Metastasis 13:57-62.

Moonen G, Grau-Wagemans MP, Selak I (1982) Plasminogen activatorplasmin system and neuronal migration. Nature 298:753-755.

Nakagawa T, Kubota T, Kabuto M, Sato K, Kawano H, Hayakawa T, Okada Y (1994) Production of matrix metalloproteinases and tissue inhibitor of metalloproteinases-1 by human brain tumors. J Neurosurg 81:69-77.

Nordstrom LA, Lochner J, Yeung W, Ciment G (1995) The metalloproteinase stromelysin-1 (transin) mediates PC12 cell growth cone invasiveness through basal laminae. Mol Cell Neurosci 6:56-68.

Oberdick J, Schilling K, Smeyne RJ, Corbin JG, Bocchiaro C, Morgan JI (1993) Control of segment-like patterns of gene expression in the mouse cerebellum. Neuron 10:1007-1018.

Okada Y, Harris Jr ED, Nagase H (1988) The precursor of a metalloendopeptidase from human rheumatoid synovial fibroblasts. Purification and mechanisms of activation by endopeptidases and 4-aminophenylmercuric acetate. Biochem J 254:731-741.

Pagenstecher A, Stalder AK, Kincaid CL, Shapiro SD, Campbell IL (1998) Differential expression of matrix metalloproteinase and tissue inhibitor of matrix metalloproteinase genes in the mouse central nervous system in normal and inflammatory states. Am J Pathol 152:729-741.

Pittman RN, Williams AG (1989) Neurite penetration into collagen gels requires $\mathrm{Ca}^{2+}$-dependent metalloproteinase activity. Dev Neurosci 11:41-51.

Polette M, Nawrocki B, Pintiaux A, Massenat C, Maquoi E, Volders L, Schaaps JP, Birembaut P, Foidart JM (1994) Expression of gelatinases $\mathrm{A}$ and $\mathrm{B}$ and their tissue inhibitors by cells of early and term human placenta and gestational endometrium. Lab Invest 71:838-846.

Qian Z, Gilbert M, Colicos M, Kandel E, Kuhl D (1993) Tissueplasminogen activator is induced as an immediate-early gene during seizure, kinding and long-term potentiation. Nature 361:453-457.

Rakic P (1971) Neuron-glia relationship during granular cell migration in developing cerebellar cortex. A Golgi and electronmicroscopic study in Macacus rhesus. J Comp Neurol 141:283-312.

Rakic P (1990) Principles of neuronal cell migration. Experientia 46:882-891.

Reichardt LF, Tomaselli KJ (1991) Extracellular matrix molecules and their receptors: functions in neural development. Annu Rev Neurosci 14:531-570.

Rex M, Church R, Tointon K, Ichihashi RM, Mokhtar S, Uwanogho D, Sharpe PT, Scotting PJ (1998) Granule cell development in the cerebellum is punctuated by changes in Sox gene expression. Brain Res Mol Brain Res 55:28-34.

Rosenberg GA, Kornfeld M, Estrada E, Kelley RO, Liotta LA, StetlerStevenson WG (1992) TIMP-2 reduces proteolytic opening of bloodbrain barrier by type IV collagenase. Brain Res 576:203-207.

Seeds NW, Haffke S, Christensen K, Schoonmaker J (1990) Cerebellar granule cell migration involves proteolysis. Adv Exp Biol Med 265:169-178.

Seeds NW, Williams BL, Bickford PK (1995) Tissue plasminogen activator induction in Purkinje neurons after cerebellar motor learning. Science 270:1992-1994.

Seeds NW, Friedman G, Hayden S, Thewke D, Haffke S, McGuire P, Krystosek A (1996) Plasminogen activators and their interaction with the extracellular matrix in neural development, plasticity and regeneration. Neuroscience 8:405-412. 
Sheffield JB, Krasnopolsky V, Dehlinger E (1994) Inhibition of retinal growth cone activity by specific metalloproteinase inhibitors in vitro. Dev Dyn 200:79-88.

Sotelo C, Bourrat F, Triller A (1984) Postnatal development of the inferior olivary complex in the rat. II. Topographic organization of the immature olivocerebellar projection. J Comp Neurol 222:177-199.

Strongin AY, Marmer BL, Grant GA, Goldberg GI (1993) Plasma membrane-dependent activation of the $72-\mathrm{kDa}$ type IV collagenase is prevented by complex formation with TIMP-2. J Biol Chem 268:14033-14039.

Strongin AY, Collier I, Bannikov G, Marmer BL, Grant GA, Goldberg GI (1995) Mechanism of cell surface activation of 72-kDa type IV collagenase. Isolation of the activated form of the membrane metalloprotease. J Biol Chem 270:5331-5338.

Talhouk RS, Bissell M, Werb Z (1992) Coordinated expression of extracellular matrix-degrading proteinases and their inhibitors regulates mammary epithelial function during involution. J Cell Biol 118:1271-1282.

Tao Y, Black IB, DiCicco-Bloom E (1996) Neurogenesis in neonatal rat brain is regulated by peripheral injection of basic fibroblast growth factor (bFGF). J Comp Neurol 376:653-663.

Thomasset N, Lochter A, Sympson CJ, Lund LR, Williams DR, Behrendtsen O, Werb Z, Bissell MJ (1998) Expression of autoactivated stromelysin-1 in mammary glands of transgenic mice leads to a reactive stroma during early development. Am J Pathol 153:457-467.

Uhm JH, Dooley NP, Oh LY, Yong VW (1998) Oligodendrocytes utilize a matrix metalloproteinase, MMP-9, to extend processes along an astrocyte extracellular matrix. Glia 22:53-63.

Van Heusden J, de Jong P, Ramaekers F, Bruwiere H, Borgers M, Smets G (1997) Fluorescein-labeled tyramide strongly enhances the detection of low bromodeoxyuridine incorporation levels. J Histochem Cytochem 45:315-319.

Wassef M, Cholley B, Heizmann CW, Sotelo C (1992) Development of the olivocerebellar projection in the rat. II. Matching of the developmental compartmentations of the cerebellum and inferior olive through the projection map. J Comp Neurol 323:537-550.

Will H, Atkinson SJ, Butler GS, Smith B, Murphy G (1996) The soluble catalytic domain of membrane type 1 matrix metalloproteinase cleaves the propeptide of progelatinase A and initiates autoproteolytic activation. Regulation by TIMP-2 and TIMP-3. J Biol Chem 271:17119-17123.

Zeng Y, Rosborough RC, Li Y, Gupta AR, Bennett J (1998) Temporal and spatial regulation of gene expression mediated by the promoter for the human tissue inhibitor of metalloproteinases-3 (TIMP-3)-encoding gene. Dev Dyn 211:228-237. 